\title{
Strates
}

STRATES Matériaux pour la recherche en sciences sociales

$3 \mid 1988$

Mélanges

\section{Autour de Paris : Acteurs de la périurbanisation}

\section{Monique Roussel}

\section{(2) OpenEdition}

\section{Journals}

\section{Édition électronique}

URL : http://journals.openedition.org/strates/318

DOI : $10.4000 /$ strates. 318

ISSN : 1777-5442

Éditeur

Laboratoire Ladyss

Édition imprimée

Date de publication : 1 janvier 1988

ISSN : 0768-8067

Référence électronique

Monique Roussel, «Autour de Paris : Acteurs de la périurbanisation », Strates [En ligne], 3 | 1988, mis en ligne le 08 décembre 2004, consulté le 08 septembre 2020. URL : http://journals.openedition.org/ strates/318; DOI : https://doi.org/10.4000/strates.318

Ce document a été généré automatiquement le 8 septembre 2020.

Tous droits réservés 


\section{Autour de Paris : Acteurs de la périurbanisation}

Monique Roussel 